\title{
TURNOVER INTENTIONS? SYMPTOMS ON JOB SATISFACTION AND JOB INSECURITY IN THE FACE OF A PANDEMIC
}

\author{
Arief Dwi Saputra ${ }^{*}$, Alfina Rahmatia ${ }^{2}$, Arni Surwanti ${ }^{3}$ \\ 1,3Universitas Muhammadiyah Yogyakarta \\ 2Universitas Ahmad Dahlan
}

\begin{abstract}
Turnover intention is the permanent resignation of employees voluntarily (voluntary) or not (involuntary) from an organization. In fact, human resources are an investment for the organization. This study will attempt to review the symptoms that occur during a pandemic through a review of Turnover Intentions obtained by job satisfaction and job imperfections. This study aims to see the effect of job satisfaction and job insecurity on turnover intentions in the case study of the Presidium business unit. The object of this research is the Marketing Executive with a saturated sample technique method and a questionnaire to 158 respondents. Data were analyzed using the SPSS 22 application, traffic conclusions with multiple data analysis techniques. The results of this study can ignore that the variables of job satisfaction and job insecurity have a positive influence on turnover intention. This explains that Turnover Intentions are a symptom that occurs during a pandemic. The implications for the findings of the review results can be used as insights for organizations in facing a pandemic period and can become a future research agenda for a more comprehensive organizational review.
\end{abstract}

Keywords: turnover intentions, job satisfaction, job insecurity, pandemic period

\section{INTRODUCTION}

Currently, many companies realize that human resources are the most important company case. Because it is through human resources that causes other resources in the company to function or run (Rivai \& Sagala 2013). This is what makes human resources an important investment for many companies or organizations. The shift in the paradigm regarding human resource development has changed the systematic management of human resources from functional to strategic in nature (Sumardjo \& Mahendro 2018).
Moreover, it is added to the current pandemic. With the emergence of the corona virus (Covid-19) pandemic that occurred suddenly at the beginning of this year, it had a huge impact on people's lives, including the economy. This condition not only disrupts the economy but also disrupts the movement of the Indonesian economy based on data for the first quarter of 2020 of $2.97 \%$ (year-on-year), slowing down compared to its achievement in the first quarter of 2019 which is $5.7 \%$ (Badan Pusat Statistik 2020). This is closely related to the MSME business movement with social 
restriction policies which have an impact on reducing business activities and turnover intention.

Turnover Intention is formed and triggered by several attitude variables that affect work systematic (Zhao and Liu 2013). This will involve job satisfaction which is an individual affective reaction to their environment or work (Bamber \& Iyer, 2012). Someone with a high level of job satisfaction will have the intention to show a positive attitude, on the other hand someone with a low level of job satisfaction (dissatisfied) will show a negative attitude towards their job (Robbins 2015).

Moreover, a situation like this will create job insecurity. This condition is related to the fear of someone losing their job, the prospect of demotion or demotion or a more promising job offer and various other threats to working conditions that are associated with decreased psychological well-being (Keim et al. 2014). Then job insecurity also generates feelings of anxiety, worry, stress, and feeling uncertain in relation to the nature and existence of the next job that is felt by workers (Sabda and Dewi 2016).

Based on the above background, the researcher wanted to review the new symptoms that appeared during the pandemic due to turnover intention with the influence of job satisfaction and job insecurity in the Marketing Executive of the Presidium business unit. Which incidentally is a business unit that masterminds the business in batik products of Muhammadiyah schools throughout Indonesia. Initiated by the Muhammadiyah Student Association organization movement (IPM 2018).

Its employees are also students who are members of the Muhammadiyah Student Association. It becomes interesting because the object of research is students. As we all know that the task of students is to study, but there are students who have started their career by working. With his duties as a student but also required to work professionally, either voluntarily or involuntary.

\section{LITERATURE REVIEW AND RESEARCH MODEL DEVELOPMENT}

Each employee individually has different job satisfaction, even though they are in the same type of job, this depends on the level of their needs and the system that applies to them. Javed et al., (2014), states that job satisfaction is a person's feeling and assessment of his job, especially regarding his working conditions, in relation to whether his job can meet his expectations, needs and desires.

Job satisfaction is one element that is quite important in the organization. This is because job satisfaction can affect work behavior such as being lazy, diligent, productive, etc., or having a relationship with several types of behavior that are very important in organizations (Bashir Ahmed 2012). On the other hand, pleasant or unpleasant emotional states in where employees perceive their job will also affect job satisfaction.

However, job satisfaction will be related to the pleasant psychological state felt by workers in a work environment because their needs are met adequately. This also causes the desire to make a turnover because it is closely related to the resignation of employees if the work environment is not pleasant (Mishra 2013). In addition, job satisfaction will have an impact on emotional attitudes to work which is reflected by work morale, discipline, and work performance which will have an impact on turnover intentions (Arief, 2020).

\section{Job Insecurity}

Job insecurity or can be called job insecurity can be defined as a condition 
related to a person's fear of losing their job or the prospect of demotion or demotion and various other threats to working conditions that are associated with decreased psychological well-being and decreased job satisfaction (Ellonen and Nätti 2015). Job insecurity is also defined as feeling tense, anxious, worried, stressed, and feeling uncertain in relation to the nature and existence of the next job that is felt by workers (Huang et al., 2012).

Furthermore, creating a desire to always work harder will avoid the risk of a person's job insecurity. Short-term (contract) work will result in uncertainty. This is what Ghosh (2017) explains that aspects of job insecurity include fear of losing a job, working harder, and fear of losing social status which will have an impact on turnover intentions.

In addition, (Staufenbiel and König 2010), the uncertainty of job insecurity will have an effect on turnover intentions that accompany a job because it causes anxiety or insecurity about the consequences of the job, which includes unsettled placement or uncertainty about salary issues and the opportunity to get a promotion or training. Psychological contract theory (psychological contract theory) states that the uncertainty in the organization will cause serious problems, one of which is job insecurity which can impact on the desire to resign (Balz and Schuller 2018).

\section{Relational Job Satisfaction and Turnover Intentions}

Olaniyan \& Hystad (2016) states that turnover intention is the level or intensity of wanting to leave the company, there are many reasons that cause the desire to leave the company and one of them is the desire to get a better job. On the other hand, the tendency or intention of employees to stop working voluntarily or move from one place to another according to their own choice, while external factors include layoffs (Termination of Employment) (Di Stefano, Venza, and Aiello 2020). The intention to continue working in the organization is a reflection that can illustrate every commitment made by employees to the organization (Yücel 2012).

Positive intentions in the form of a desire to continue to stay in the organization provide more benefits for the organization than the desire to leave the organization. however, there are many factors that create an individual's desire to move. These factors include job satisfaction and employee job discomfort (Juhdi, Pa'wan, and Hansaram 2013). This research is reinforced by the statement put forward by (Vesa, et al., 2014) which states that the tendency to leave the company or organization is related to job satisfaction and job insecurity.

H1: Job Satisfaction has a positive effect on turnover intentions

\section{Relational Job Insecurity and Turnover Intention}

Qureshi \& Khan (2016) suggest that job insecurity conditions and job satisfaction will affect organizational commitment and organizational trust which in turn has a relationship with the desire to move employees from the company where the employee works. Job insecurity conditions that are felt by employees will affect the level of job satisfaction of an employee with the company or organization and employee trust in the organization which is ultimately related to the desire of the employee concerned to find other job alternatives.

Callea et al., (2016) suggest that a decrease in working conditions such as the emergence of job insecurity conditions, will reduce the quality of an individual not only from his job, but also lead to the emergence of a sense of loss of dignity which ultimately 
reduces the psychological condition of the employee concerned. In the long term, this condition will lead to dissatisfaction in work and will lead to turnover intentions.

Zheng et al., (2014) suggest that the job insecurity conditions that employees perceive will affect their attitudinal reactions, such as the desire to leave work, decreased satisfaction that employees have with the company or organization the employee has at work. Based on some of these opinions, it can be concluded that the job insecurity conditions felt by employees will affect the level of job satisfaction that employees have with the company or organization, the commitment that employees have to the company or organization and the employee's desire to quit their job and the desire to move employees from the company where the employee is concerned. work.

H2: Job Insecurity has a positive effect on turnover intentions

\section{METHOD}

This study aims to determine the effect of job satisfaction (JS) and job insecurity (JI) on turnover intentions (TI). This study using quantitative research with a correlational method approach. For data collection, it was taken from a sample representing the population under study with a saturated sample technique (Sugiyono 2012). To answer the problems that have been described and answer the hypotheses proposed in the study also require valid and accountable data, researchers use data collection techniques including questionnaires with a Likert scale. Based on the data collected, data processing is carried out using the SPSS 22 application. With the aim of providing an overview and testing the hypotheses that have been stated regarding the effect of job satisfaction and job insecurity on Turnover Intentions on the executive marketing of the Presidium business unit through validity tests, reliability tests, significance tests partial (t-test), and simultaneous significance test (F-test).

\section{RESULT AND DISCUSSION}

In this test, the researcher uses the product moment correlation test, and in providing an interpretation of the item correlation coefficient that has a positive correlation with (total score) and high correlation, it shows that the item has high validity. To be considered eligible if $r_{\text {count }} \geq \alpha$ (0.361). Details of the validity test results can be seen in tables 1-3.

Table 1-3 shows that the correlation between each indicator to the construct of each variable shows a significant result. And shows that $r$ count is greater than $r$ table. So, it can be concluded that all questionstatement items are declared valid.

Table 1. Job Satisfaction Validity Test Results

\begin{tabular}{cccc}
\hline & R count & R table & Result \\
\hline $\mathrm{X} 1.1$ & 0.471 & 0.361 & Valid \\
$\mathrm{X} 1.2$ & 0.391 & 0.361 & Valid \\
$\mathrm{X} 1.3$ & 0.381 & 0.361 & Valid \\
$\mathrm{X} 1.4$ & 0.548 & 0.361 & Valid \\
$\mathrm{X} 1.5$ & 0.418 & 0.361 & Valid \\
Skortot & 1.000 & & \\
\hline
\end{tabular}

Table 2. Job Insecurity Validity Test Results

\begin{tabular}{cccc}
\hline & R count & R table & Result \\
\hline X2.1 & 0.423 & 0.361 & Valid \\
X2.2 & 0.481 & 0.361 & Valid \\
X2.3 & 0.464 & 0.361 & Valid \\
X2.4 & 0.663 & 0.361 & Valid \\
X2.5 & 0.588 & 0.361 & Valid \\
Skortot & 1.000 & & \\
\hline
\end{tabular}


Table 3. Turnover Intention Validity Test Results

\begin{tabular}{cccc}
\hline & R count & R table & Result \\
\hline Y1.1 & 0.543 & 0.361 & Valid \\
Y1.2 & 0.441 & 0.361 & Valid \\
Y1.3 & 0.644 & 0.361 & Valid \\
Y1.4 & 0.566 & 0.361 & Valid \\
Y1.5 & 0.389 & 0.361 & Valid \\
Skortot & 1.000 & & \\
\hline
\end{tabular}

\section{Reliability Test}

Reliability testing is carried out after validity testing and is carried out on all valid questions. The question item can be said to be reliable if the Cronbach alpha value is greater than 0.6. $r_{\text {count }} \geq \alpha(\alpha=0.7)$. For more details, see Table 4.

Table 4. Reliability Test Results

\begin{tabular}{lcccc}
\hline $\begin{array}{l}\text { Vari } \\
\text { able }\end{array}$ & $\begin{array}{c}\text { N of } \\
\text { items }\end{array}$ & Alpha & r-table & Result \\
\hline JS & 5 & 0,973 & 0,7 & Reliable \\
JI & 5 & 0,972 & 0,7 & Reliable \\
TI & 5 & 0,950 & 0,7 & Reliable \\
\hline
\end{tabular}

Table 4 shows that all variables have an alpha coefficient above 0.7 so that it can be said that all the measuring concepts of each variable from the questionnaire are reliable.

\section{Characteristics of Respondents Based on Age}

From the Table 5, it is known that the characteristics of respondents based on age are 2 respondents or $3.4 \%$, namely aged less than 15 years, 17 respondents or $29.3 \%$ aged between 16-18 years, 25 respondents or 43.3 percent aged between $19-21$ years, and 14 respondents or $24.1 \%$ who are more than 22 years old. From these data, it can be concluded that the highest majority of respondents are aged 19-21 years.
Table 5. Characteristics of Respondents Based on Age

\begin{tabular}{cccc}
\hline No & Age & Total & Percentage \\
\hline 1 & 15 & 27 & $3,4 \%$ \\
2 & $16-18$ & 42 & $29,3 \%$ \\
3 & $19-21$ & 50 & $43,1 \%$ \\
4 & $>22$ & 39 & $24,1 \%$ \\
\hline & Total & 158 & $100 \%$ \\
\hline
\end{tabular}

Characteristics of Respondents Based on Education

From the results on Table 6 shows that the number of respondents seen from the majority of education is high school education, namely 40 people or $31 \%$, while for undergraduate education is 18 people or $69 \%$.

Table 6. Characteristics of Respondents by Education

\begin{tabular}{cccc}
\hline No. & Education & Total & Percentage \\
\hline 1 & SMA & 68 & $31 \%$ \\
2 & S1 & 90 & $69 \%$ \\
\hline & Total & 158 & $100 \%$ \\
\hline
\end{tabular}

\section{Characteristics of Respondents Based on Length of Employment}

From the results on Table 7, it shows that the number of respondents seen from the length of work, the highest majority is less than 1 year, namely 42 people or $72.4 \%$, while the 1 3 years of work are 15 people or $25.9 \%$, and the length of work is more than 1 year is 1 person with a percentage of $1.7 \%$.

Table 7. Characteristics of Respondents Based on Length of Employment

\begin{tabular}{cccc}
\hline No. & $\begin{array}{c}\text { Length of } \\
\text { Employment }\end{array}$ & Total & Percentage \\
\hline 1 & $<1$ year & 75 & $72,4 \%$ \\
2 & $1-3$ year(s) & 48 & $25,9 \%$ \\
3 & $>3$ years & 34 & $1,7 \%$ \\
\hline & Total & 158 & $100 \%$ \\
\hline
\end{tabular}




\section{Multiple Regression Test}

To find out how far the effect of Job Satisfaction (X1) and Job Insecurity (X2) on Turnover Intentions $(\mathrm{Y})$, multiple linear regression tests were used, so based on the results of distributing questionnaires to the executive marketing of the Presidium business unit as many as 158 questionnaires and data processing was carried out with the results on Table 8.

\section{Table 8. Coefficients ${ }^{a}$}

\begin{tabular}{|c|c|c|c|c|}
\hline \multirow[b]{3}{*}{ Model } & \multicolumn{2}{|c|}{ Coefficients $^{a}$} & \multirow[b]{3}{*}{$\mathrm{t}$} & \multirow[b]{3}{*}{ Sig. } \\
\hline & \multicolumn{2}{|c|}{$\begin{array}{l}\text { Unstandardized } \\
\text { Coefficients }\end{array}$} & & \\
\hline & B & Std. Error & & \\
\hline Constant & 28.110 & 1.012 & 27.766 & .000 \\
\hline Total JS & .361 & .070 & 5.121 & .000 \\
\hline Total JI & .569 & .095 & 5.974 & .000 \\
\hline
\end{tabular}

From the Table 8 , it can be seen that the constant value is 28.110 , the regression coefficient for the $\mathrm{X} 1$ variable is -0.361 , the coefficient for the $\mathrm{X} 2$ variable is -0.569 from the coefficient and the constant value can be obtained from the multiple linear regression equation: $\mathrm{Y}=28.110+(-0.361) \mathrm{X} 1+(-0.569)$ $\mathrm{X} 2$ the multiple linear regression equation obtained has the meaning that constant value of 28.110 that if the variable value of Job Satisfaction (X1) and Job Insecurity (X2) is zero then Turnover Intentions $(\mathrm{Y})$ will be a constant of 28.110. At a b1 value of -0.361 , this means that the regression coefficient of the Job Satisfaction variable means that if the Job Satisfaction variable is increased by one unit, it will reduce the level of Turnover Intentions in the executive marketing of the Presidium business unit by 0.361 assuming other variables remain. Furthermore, b2 is -0.569 , this means that the regression coefficient of the Job Insecurity variable means that if the
Work Insecurity variable is increased by one unit, it will reduce the level of Turnover Intentions in the executive marketing of the Presidium business unit by 0.569 assuming other variables remain.

\section{Determination Coefficient Test}

Based on the results of the SPSS calculation, the coefficient of determination data is obtained:

\section{Table 9. Summary Model}

Summary Model

\begin{tabular}{lcccr}
\hline Model & $\mathrm{R}$ & $\begin{array}{c}\mathrm{R} \\
\text { Square }\end{array}$ & $\begin{array}{c}\text { Adjusted R } \\
\text { Square }\end{array}$ & $\begin{array}{c}\text { Std. Error of } \\
\text { the Estimate }\end{array}$ \\
\hline 1 & $.847 \mathrm{a}$ & .717 & .707 & 3.110 \\
\hline $\begin{array}{l}\text { a. Predictors: (Constant), Total Job Insecurity, Total Job } \\
\text { Satisfaction }\end{array}$
\end{tabular}

From the partial hypothesis test, it can be seen that the tsig value for the Job Satisfaction variable is 0.000 , this value when compared with the 95\% confidence level and with an $\alpha$ value of 0.05 then $t_{\text {sig }}<\alpha$ which is equal to $0.000<0.05$ with a significance of $\alpha$ of 0.000 which means that $\mathrm{H} 1$ accepted and Ho rejected, the Job Satisfaction variable has a significant effect on Turnover Intentions on the executive marketing of the Presidium business unit. The tsig value for the Job Insecurity variable is 0.000 , this value when compared with the $95 \%$ confidence level and with an $\alpha$ value of 0.05 , the $t_{\text {sig }}<\alpha$ is equal to $0.000<0.05$ with $\alpha$ significance of 0.000 , which means that $\mathrm{H} 2$ is accepted and $\mathrm{H} 0$ is rejected, the insecurity variable Work has a significant effect on the Turnover Intentions of executive marketing of the Presidium business unit.

\section{Simultaneous Significance Test (Test F)}

The F test is a test carried out to see the effect of the independent variable on the dependent variable together, Table 10 are the results obtained from calculations using SPPS 22. 
Table 10. Simultaneous Significance Test

\begin{tabular}{lrrrrr}
\multicolumn{6}{c}{ ANOVA $^{\mathbf{b}}$} \\
\hline Model & Sum of & \multicolumn{4}{c}{ Mean } \\
Squares & Df & Square & F & Sig. \\
\hline Regression & 1348.315 & 2 & 674.15 & 69.702 & .00 \\
& & 7 & $0^{\text {a }}$ \\
Residual & 531.961 & 55 & 9.672 & & \\
Total & 1880.276 & 57 & & & \\
\hline a
\end{tabular}

a. Predictors: (Constant), Total Job Insecurity, Total Job Satisfaction

b. Dependent Variable: Total Turnover

Intentions

Based on the results obtained in the Table 10 , it is known that $\mathrm{F}_{\text {count }}$ is 69.702 with $\alpha$ of 0.000 with a confidence level of $95 \%$ and $\alpha$ of 0.05 . These results indicate indicates that $\mathrm{Ha}$ is accepted, and Ho is rejected, that the Job Satisfaction and Job Insecurity variables have a significant effect on Executive Marketing Turnover Intentions in the Presidium business unit.

\section{Discussion}

The results of this study indicate that the variables of Job Satisfaction and Job Insecurity affect the Turnover Intentions of executive marketing of the Presidium business unit partially or simultaneously. This is because the implementation of turnover by the company occurs for employees with low performance, but the turnover rate must be strived so that it is not too high so that the company still has the opportunity to benefit or benefit from increased performance from employees that is greater than the recruitment costs borne by the organization (Sugiono 2019).

This is in line with the research results. According to Ekhsan (2019) job satisfaction affects a person's desire to leave the organization. The process of leaving someone from a company begins with an increase in job dissatisfaction from employees. The results of this study explain that if Job Satisfaction increases, it will reduce Turnover Intentions on the executive marketing of the Presidium business unit with the effect of reaching $36.1 \%$. In addition, this study also explains that vulnerable people aged 19-21 years $(43.3 \%)$ tend to resign. In a study conducted by Jang \& George (2012) job satisfaction and turnover intention have a close relationship of $67.40 \%$ in terms of the same age as in this study.

This study also explains that the effect that causes the 19 - 21 years old to be vulnerable to turnover intentions is because at this age the tendency to explore themselves and try new things is still too high. In addition, in education with an undergraduate level (69\%), the same thing was obtained regarding turnover intentions because they did not have much work experience, coupled with the current pandemic conditions. This is also expressed by Waleed et al., (2019) who found that job satisfaction has a positive and significant correlation with turnover intention in terms of age and education level.

Furthermore, Ratnasari \& Lestari (2020) states that job insecurity has a positive relationship with turnover intention due to the instability of employment status and unpredictable income levels, which results in turnover intention which tends to increase. This explains that the length of work, especially under 1 year (72.4\%) in this study, has resulted in a tendency to make a turnover intention. Qazi et al. (2015) in their research also states that there is a positive relationship between job insecurity and turnover intention, the higher the level of job insecurity felt by employees, the higher the employee's intention to leave the company.

In the research of Mauno et al., (2014) which also strengthens this study also states that job insecurity has a significant effect on turnover intention. When employees feel that 
there is a risk of losing their job, the employee's intention to leave the company increases with the desire to change jobs. However, this study explains that if there is an increase in Job Insecurity, it will reduce Turnover Intentions in the Executive Marketing of the Presidium business unit with the effect of reaching 56.9\%. Turnover intention for employees can be said as resignation, voluntary, or voluntary (involuntary) from an organization. High turnover is dangerous for the company, and it also reduces the efficiency and productivity of the organization. The negative effect of the high employee turnover rate can also cause a large waste of costs because the company has to invest costs for recruitment, orientation, training, overtime (overtime), and supervision (Fauzi et al., 2020).

However, this study also explains that respondents with a length of work for 1-3 years (25.9\%) and over the age of 22 tend not to want to do turnover intentions, due to the pandemic period. On the other hand, adaptability and difficulty finding work are reasons to stay on the job. Turnover prevention leads to the ultimate reality faced by an organization in the form of the number of employees leaving the organization in a certain period. Therefore, in dealing with turnover intention, individual evaluation that refers to the results is required (Jung, 2014).

\section{CONCLUSION AND IMPLICATION Conclusion}

Research results in this study indicate that the variables of Job Satisfaction and Job Insecurity affect the Turnover Intentions of executive marketing of the Presidium business unit partially or simultaneously in the executive marketing of the Presidium business unit. This study also explains that the age characteristics of $19-25$ years (43.3\%), education with an undergraduate level (69\%) and a length of work of less than 1 year $(72.4 \%)$ also influence the tendency to make turnover intention.

Several factors in the variables in this study explain the effect of turnover intentions on the desire to explore self, the desire to try new things, experience, instability in employment status and unpredictable income levels, especially coupled with the current pandemic conditions. Furthermore, this study suggests that if there is an increase in Job Insecurity, it will reduce Turnover Intentions with the effect of reaching $56.9 \%$ and an increase in Job Satisfaction, it will reduce Turnover Intentions with an effect of reaching $36.1 \%$ on the Executive Marketing of the Presidium business unit. There are some respondents with a length of work for 1-3 years $(25.9 \%)$ and those over the age of 22 who tend not to want to make turnover intentions because the difficulty of finding work is a reason to stay on the job during the pandemic.

\section{Managerial Implication}

Along with the development of an organization, various kinds of problems arise related to human resources. Coupled with organizations that are struggling and facing a pandemic to restore managerial systems. One of the serious problems that exist in human resources is the behavior of employee turnover intention caused by job satisfaction and job insecurity. Turnover intentions for employees can be considered as permanent voluntary or involuntary resignations from an organization. High turnover is dangerous for the company, and it also reduces the efficiency and productivity of the organization. The negative effect of the high employee turnover rate can also lead to a significant waste of costs because the company has to invest costs for recruitment, orientation, training, overtime (overtime), and supervision. 
The importance of increasing job satisfaction and minimizing job insecurity has implications for organizations. This is due to reduce turnover intentions. Other factors caused by a pandemic such as the desire to explore self, the desire to try new things, experience, employment status and unpredictable income levels can be reduced to support organizational stability and productivity. In the managerial process, organizations can prioritize attention to education with an undergraduate level, 19-21 years of age with a length of work under 1 year that tends to stop working. On the other hand, if the organization wants to open recruitment, the factors of age, level of education and work experience can be reviewed in more depth to support the process and the running of the organization. Turnover prevention leads to the ultimate reality faced by an organization in the form of the number of employees leaving the organization in a certain period. Therefore, in dealing with turnover intention, individual evaluation that refers to the results is required.

With the organizational efforts of the workforce in increasing job satisfaction and minimizing job insecurity, you will have the attitude to survive, fight and support continuation and provide a sense of security for work in the organization. Job satisfaction and job security are very important job guarantees, so that employees will feel satisfied and safe to avoid feeling threatened at work, thereby increasing productivity and very high work commitment and the possibility of wanting to change jobs.

\section{Suggestion and Research Limitation}

This study offers important findings in explaining the relationship between job satisfaction and job insecurity and turnover intentions in organizations. But this study also has some drawbacks. The use of the approach with questionnaire data collection is a limitation of this problem. This is because the pandemic period reduces the opportunity to collect data in other ways such as, in-depth interviews and observations. The difficulty in meeting respondents and distributing questionnaires directly became a separate obstacle in this study with only 158 respondents. This study can also be used as a reference for future research and can be developed for researchers for academics, managers or employees for practice, and managerial systems for organizations. This study can be expanded by examining a larger organization and a more comprehensive variable with the aim of dealing with unexpected moments such as during the current pandemic.

\section{REFERENCES}

Al-Ali, Waleed, Ali Ameen, Osama Isaac, Gamal S. A. Khalifa, and Ahmed Hamoud Shibami. 2019. "The Mediating Effect of Job Happiness on the Relationship between Job Satisfaction and Employee Performance and Turnover Intentions: A Case Study on the Oil and Gas Industry in the United Arab Emirates." Journal of Business \& Retail Management Research 13 (04): 103-16. https://doi.org/10.24052/jbrmr/v13is04/art-09.

Arief Dwi Saputra. 2020. Pelajar Berwirausaha. Why Not? Palangka Raya: CV. Narasi Nara. 
Badan Pusat Statistik. 2020. "Statistik Pertumbuhan Ekonomi Indonesia Triwulan I-2020." Pertumbuhan Ekonomi Indonesia Triwulan IV-2019, no. 17: 2. https://www.bps.go.id/pressrelease/2020/02/05/1755/ekonomi-indonesia-2019tumbuh-5-02-persen.html.

Balz, Anne, and Karin Schuller. 2018. "Always Looking for Something Better? The Impact of Job Insecurity on Turnover Intentions: Do Employables and Irreplaceables React Differently?" Economic and Industrial Democracy, 1-18. https://doi.org/10.1177/0143831X18757058.

Bashir Ahmed. 2012. "Organizational Ethics and Job Satisfaction: Evidence from Pakistan." African Journal of Business Management 6 (8): 2966-73. https://doi.org/10.5897/ajbm11.2107.

Callea, Antonino, Flavio Urbini, Emanuela Ingusci, and Antonio Chirumbolo. 2016. "The Relationship between Contract Type and Job Satisfaction in a Mediated Moderation Model: The Role of Job Insecurity and Psychological Contract Violation." Economic and Industrial Democracy 37 (2): 399-420. https://doi.org/10.1177/0143831X14546238.

E. Michael Bamber \& M. Iyer. 2012. “Big 5 Auditors' Professional and Organizational Identification: Consistency or Conflict?" A Journal of Practice 21 (2): 21-38. https://doi.org/https://doi.org/10.2308/aud.2002.21.2.21.

Ekhsan, Muhamad. 2019. "The Influence Job Satisfaction and Organizational Commitment on Employee Turnover Intention." Management, and Accounting 1 (1): 48-55. http://ejournal.stie-kusumanegara.ac.id.

Ellonen, Noora, and Jouko Nätti. 2015. "Job Insecurity and the Unemployment Rate: Micro- and Macro-Level Predictors of Perceived Job Insecurity among Finnish Employees 1984-2008." Economic and Industrial Democracy 36 (1): 51-71. https://doi.org/10.1177/0143831X13495720.

Fauzi, Muhammad, Amir Hasan, and Vera Oktari. 2020. "CURRENT Jurnal Kajian Akuntansi Dan Bisnis Terkini." Jurnal Kajian Akuntansi Dan Bisnis Terkini 1 (1): 89-105.

Ghosh, Sumit Kumar. 2017. "The Direct and Interactive Effects of Job Insecurity and Job Embeddedness on Unethical Pro-Organizational Behavior: An Empirical Examination." Personnel Review 46 (6): 1182-98. https://doi.org/10.1108/PR-05-2015-0126.

Huang, Niu, Lee, Susan. 2012. "Differentiating Cognitive and Affective Job Insecurity: Antecedents and Outcomes." Journal of Organizational Behavior 60 (1): 5-22. https://doi.org/10.1002/job.

IPM. 2018. Data Studentpreneur. Lembaga Survey PKK PP IPM. 
Jang, Jichul, and R. Thomas George. 2012. "Understanding the Influence of Polychronicity on Job Satisfaction and Turnover Intention: A Study of Non-Supervisory Hotel Employees." International Journal of Hospitality Management 31 (2): 588-95. https://doi.org/10.1016/j.ijhm.2011.08.004.

Javed, Masooma, Rifat Balouch, and Fatima Hassan. 2014. "Determinants of Job Satisfaction and Its Impact on Employee Performance and Turnover Intentions." International Journal of Learning and Development 4 (2): 120-40. https://doi.org/10.5296/ijld.v4i2.6094.

Juhdi, Nurita, Fatimah Pa'wan, and Ram Milah Kaur Hansaram. 2013. "HR Practices and Turnover Intention: The Mediating Roles of Organizational Commitment and Organizational Engagement in a Selected Region in Malaysia." International Journal of Human Resource Management 24 (15): 3002-19. https://doi.org/10.1080/09585192.2013.763841.

Jung, Chan Su. 2014. "Why Are Goals Important in the Public Sector? Exploring the Benefits of Goal Clarity for Reducing Turnover Intention." Journal of Public Administration Research and Theory 24 (1): 209-34. https://doi.org/10.1093/jopart/mus058.

Keim, Alaina C., Ronald S. Landis, Charles A. Pierce, and David R. Earnest. 2014. "Why Do Employees Worry about Their Jobs? A Meta-Analytic Review of Predictors of Job Insecurity." Journal of Occupational Health Psychology 19 (3): 269-90. https://doi.org/10.1037/a0036743.

Mauno, Saija, Nele De Cuyper, Asko Tolvanen, Ulla Kinnunen, and Anne Mäkikangas. 2014. "Occupational Well-Being as a Mediator between Job Insecurity and Turnover Intention: Findings at the Individual and Work Department Levels." European Journal of Work and Organizational Psychology 23 (3): 381-93. https://doi.org/10.1080/1359432X.2012.752896.

Mishra. 2013. “Job Satisfaction." Hospital Administration in Canada 16 (7): 30-34. https://doi.org/10.9790/1959-1454554.

Olaniyan, Oyeniyi Samuel, and Sigurd W. Hystad. 2016. “Employees' Psychological Capital, Job Satisfaction, Insecurity, and Intentions to Quit: The Direct and Indirect Effects of Authentic Leadership." Revista de Psicologia Del Trabajo y de Las Organizaciones 32 (3): 163-71. https://doi.org/10.1016/j.rpto.2016.09.003.

Qureshi, M. A., \& Khan, M. A. 2016. “Organizational and Psychological Outcomes of Job Insecurity: A Cross Sectional Investigation in the Private Sector Organizations of Pakistan Using Subjective Approach of Job Insecurity." Pakistan Business Review 18 (1): 19-36.

Ratnasari, Sri Langgeng, and Linayati Lestari. 2020. "Effect of Leadership Style, Workload and Job Insecurity on Turnover Intention." International Journal of Innovation, Creativity and Change 11 (12): 299-313. 
Rivai \& Sagala. 2013. Manajemen Sumber Daya Manusia Untuk Perusahaan Dari Teori Ke Praktik. jakarta: PT. Rajagrafindo Persada.

Robbins, S.P. 2015. Organizational Behavior. United Kingdom: Pearson.

Sabda, Gde, and Anak Dewi. 2016. "Pengaruh Job Insecurty Terhadap Kepuasan Kerja Dan Turnover Intention Karyawan Kontrak Di Bali Dynasty Resort.” None 5 (6): 254051.

Staufenbiel, Thomas, and Cornelius J. König. 2010. "A Model for the Effects of Job Insecurity on Performance, Turnover Intention, and Absenteeism." Journal of Occupational and Organizational Psychology 83 (1): 101-17. https://doi.org/10.1348/096317908X401912.

Stefano, Giovanni Di, Gaetano Venza, and Davide Aiello. 2020. “Associations of Job Insecurity With Perceived Work-Related Symptoms, Job Satisfaction, and Turnover Intentions: The Mediating Role of Leader-Member Exchange and the Moderating Role of Organizational Support." Frontiers in Psychology 11 (July): $1-9$. https://doi.org/10.3389/fpsyg.2020.01329.

Sugiono, Edi. 2019. “Analysis of Job Insecurity, Job Satisfaction and Organizational Culture on Turnover Intention Mediated by Organizational Commitments in PT. Seraphim Life Center, Jakarta." Journal of Resources Development and Management 59: 17-25. https://doi.org/10.7176/jrdm/59-03.

Sugiyono. 2012. Metodologi Penelitian Bisnis. Bandung: Alfabeta.

Sumardjo \& Mahendro, Donni Juni Priansa. 2018. Manajemen Pengembangan Sumber Daya Manusia (9 Konsep-Konsep Kunci). https://doi.org/10.35673/ajmpi.v7i1.308.

Vesa, David, Fabian. 2014. “Organizational Embeddedness, Turnover Intentions, and Voluntary Turnover: The Moderating Effects of Employee Demographic Characteristics and Value Orientations." Journal of Organizational Behavior 60 (1): 5-22. https://doi.org/10.1002/job.1981.

Yücel, Ilhami. 2012. "Examining the Relationships among Job Satisfaction, Organizational Commitment, and Turnover Intention: An Empirical Study." International Journal of Business and Management 7 (20): 44-58. https://doi.org/10.5539/ijbm.v7n20p44.

Zhao, Erdong, and Liwei Liu. 2013. "Comments on Development of Job Embeddedness about Study on Turnover and Exploration into Application in Enterprises." Asian Social Science 6 (6): 63-72. https://doi.org/10.5539/ass.v6n6p63.

Zheng, Xingshan, Ismael Diaz, Ningyu Tang, and Kongshun Tang. 2014. "Job Insecurity and Job Satisfaction: The Interactively Moderating Effects of Optimism and Person-Supervisor Deep-Level Similarity." Career Development International 19 (4): 426-46. https://doi.org/10.1108/CDI-10-2013-0121. 